Mihail I. Kuryachiy', Vyacheslav V. Kapustin',

DOI: $10.25045 /$ jpit.v11.i1.05

Alexander S. Popov ${ }^{3}$

${ }^{1,2}$ Department of Television and Control Tomsk state university of operation systems and radio electronics, Tomsk, Russia

${ }^{3}$ Russian Television and Broadcasting Network, Kemerovo, Russia

${ }^{1}$ kur@tu.tusur.ru, ${ }^{2}$ peregnun@mail.ru, ${ }^{3}$ mailrus@bk.ru

\title{
DIGITAL ON-AIR BROADCASTING SYSTEM'S NOISE IMMUNITY LEVEL ESTIMATION METHOD, BASED ON CONSTELLATION DIAGRAM IMAGES OFDM
}

Received: 25.01.2019 Revised: 28.03.2019 Accepted: 27.06.2019

In digital terrestrial TV broadcasting is necessary to periodically monitor the quality of the digital signal in monitoring systems for digital television transmitters. Research in this area signals the following fact. During the normal operation of the transmitter, its MER should not fall below $35 \mathrm{dBm} / \mu \mathrm{V}$. However, there are cases when, at the nominal MER level, there is no television image. This is due to GPS desynchronization of the reference signal of the transmitter, and it directly affects the final image on the television receiver. To establish this fact, it is necessary to analyze the image of the star chart of the OFDM signal. The proposed method allows to assess the level of noise immunity based on the images of the constellations COFDM. This method can be used to assess the quality of the final television image in the digital terrestrial TV broadcasting.

Keywords: DVB-T2, DTV, noise immunity, MER, BER.

\section{Introduction}

It is decided to measure the number of basic parameters for the estimation of digital on-air broadcasting systems (DTV) quality. First of all, one needs to understand whether the signal strength at the receiver is sufficient, because signal reception quality directly depends of it. If the level is low, it means that there is no reliable reception, therefore, there is no sound and image. One of the important parameters of digital systems is MER (Modulation Error Ratio) which can be correlated with the signal/noise ratio in analog communication systems. Third parameter is BER (Bit Error Ratio). It describes the frequency of occurrence of mistakenly recovered bits in the demodulated data stream and for DVB standard. The last parameter is the constellation diagram which is a graph of symbol arrangement on the amplitude-phase plane formed by the accumulation in a definite time. Usually, the diagram is seen as a qualitative rather than a quantitative parameter, allowing estimating the nature of the RF input signal distortion [1]. We will about it in detail.

Aim of research

Development of a method for indirect estimation of the noise immunity level in digital on-air broadcasting systems.

Tasks of research

1. To develop a method for indirect estimation of noise immunity level in digital on-air broadcasting systems based on the constellation diagram image processing.

2. To assess the accuracy of the developed method.

\section{Proposed approach}

To achieve the aims and do the tasks of the research, the experimental measurements are carried out using a special measuring complex (figure 1). The measuring complex is designed to control and measure variables of the digital terrestrial signal DVB-T2. 


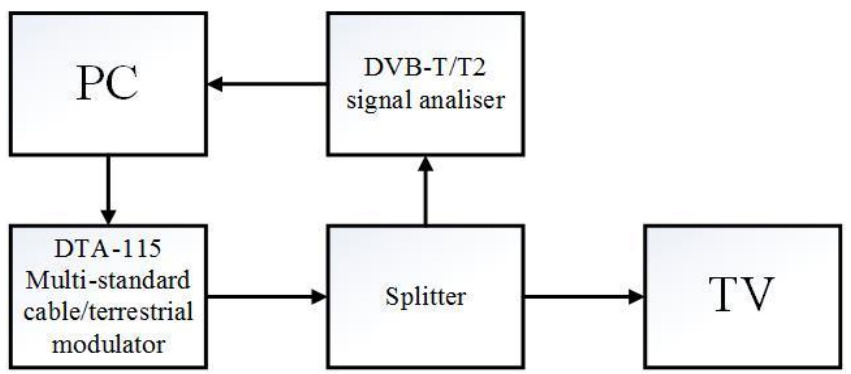

Figure 1. Block diagram of measurement system

Formation of the DVB-T2 signal was carried out using the multistandard modulator DekTec DTA-115 GOLD connected to the PC via PCI interface, TV with tuner DVB-T2 (multi-plp) DekTec's PCI modulator for most QAM-, OFDM- and VSB-based modulation standards. The DTA-115 has a programmable output level with perfect signal quality (figure 2) [2].

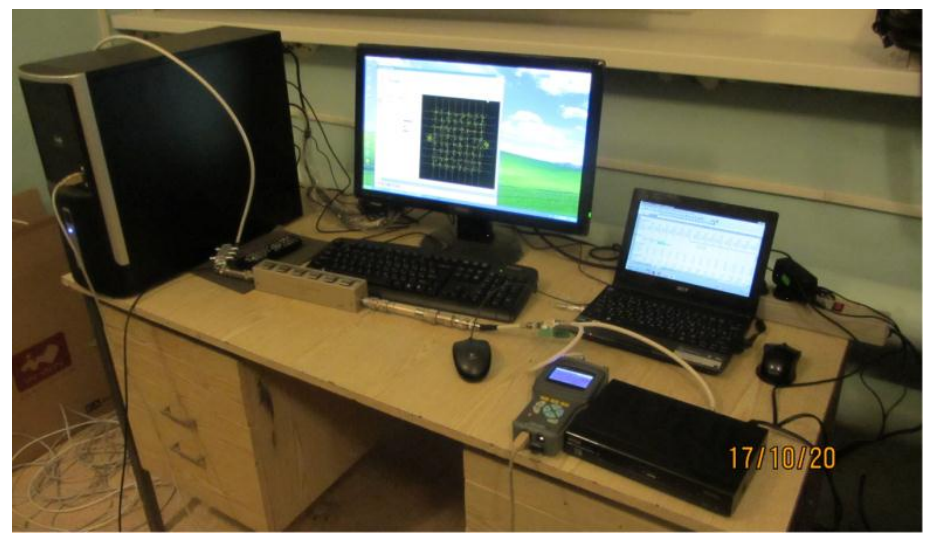

Figure 2. Laboratory in Department of Television and Control TUSUR the stand «DVB-T2»

For data transmission, the MPEG-TS transport stream with a bit rate of 22,394,118 bps is used.

The overview of known methods for image parameters estimation [3] and noise immunity of DTV systems $[4,5]$ suggests the following. The settings of first multiplex broadcasting transmitter in the city of Tomsk clocked at $474 \mathrm{MHz}$ are used as the DVB-T2 transmission parameters (table 1 , figure 3 ).

Table 1

Transmitter options

\begin{tabular}{|l|l|}
\hline Parameter & Value \\
\hline Stream type & TS \\
\hline TX mode & SISO \\
\hline FFT mode & $32 \mathrm{k}$ \\
\hline Guard interval & $1 / 32$ \\
\hline PLP modulation & $64 Q A M$ \\
\hline PLP Code Rate & $2 / 3$ \\
\hline Pilot pattern & PP4 \\
\hline Maximum bit rate & $27641574 \mathrm{bps}$ \\
\hline
\end{tabular}




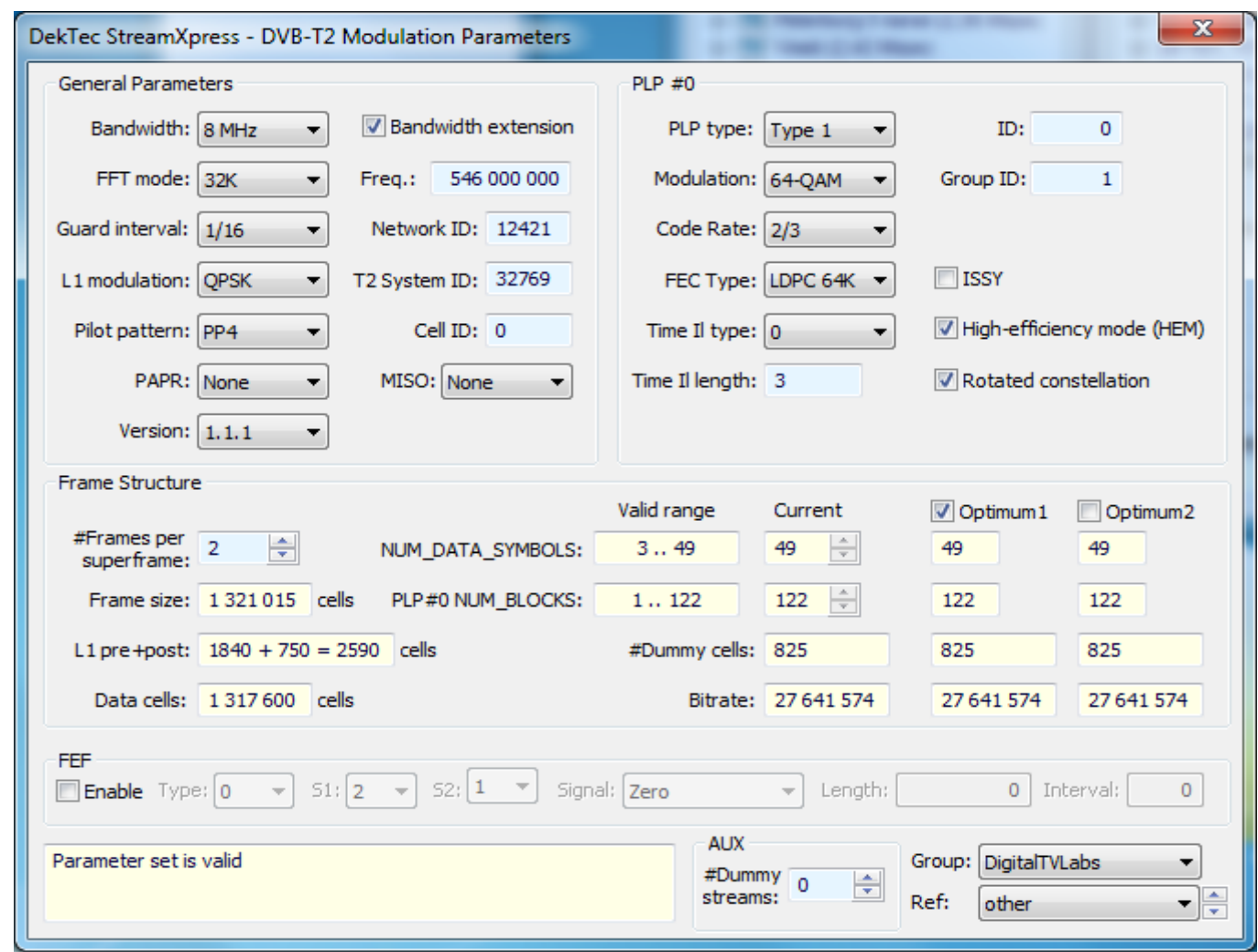

Figure 3. Signal parameters DVB-T2 in soft DekTec StreamXpress

Duration of the guard interval at the given transmission settings equals to $224 \mathrm{~ms}$.

Table 2

Signal options

\begin{tabular}{|l|l|l|l|l|l|l|}
\hline Level of signal, $\mathrm{dBuV}$ & 58,3 & 54,2 & 49,2 & 44,3 & 40,1 & 35,3 \\
\hline MER, dB & $>35$ & $>35$ & $>35$ & 31,7 & 26,9 & 20,9 \\
\hline preLBER & $1,40 \mathrm{E}-5$ & $1,50 \mathrm{E}-5$ & $1,70 \mathrm{E}-5$ & $4,10 \mathrm{E}-5$ & $1,1 \mathrm{E}-4$ & $8,5 \mathrm{E}-3$ \\
\hline postLBER & $<1,0 \mathrm{e}-8$ & $<1,0 \mathrm{e}-8$ & $<1,0 \mathrm{e}-8$ & $<1,0 \mathrm{e}-8$ & $<1,0 \mathrm{e}-8$ & $<1,0 \mathrm{e}-8$ \\
\hline
\end{tabular}

Figure 4 shows a fragment of the constellation diagram that is used for indirect estimation of DTV broadcasting system's noise immunity. It is decided to select an image area of 94x94 pixels.

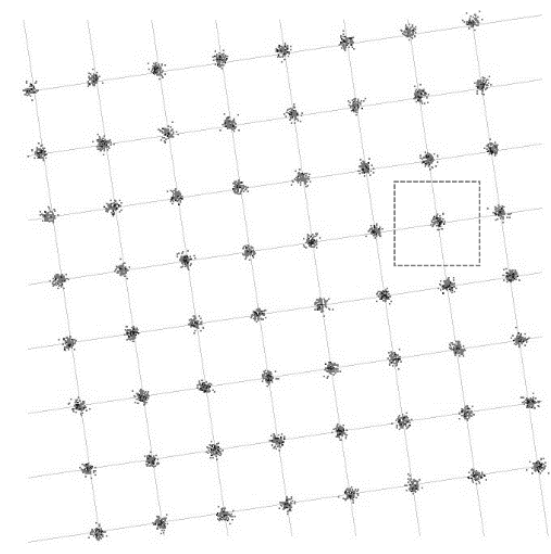

Figure 4. DVB-T2 standard signal at a level of $60 \mathrm{dBuV}$ constellation diagram (modulation 64-QAM, 32k carrier, protection interval 1/32) 
A similar area is taken from the constellation diagram image at a level of $40 \mathrm{dBuV}$ signal. Diagrams accumulation time is 30 seconds. These areas images are processed using the software plugin ImageJ (figure 5, 6) [6].

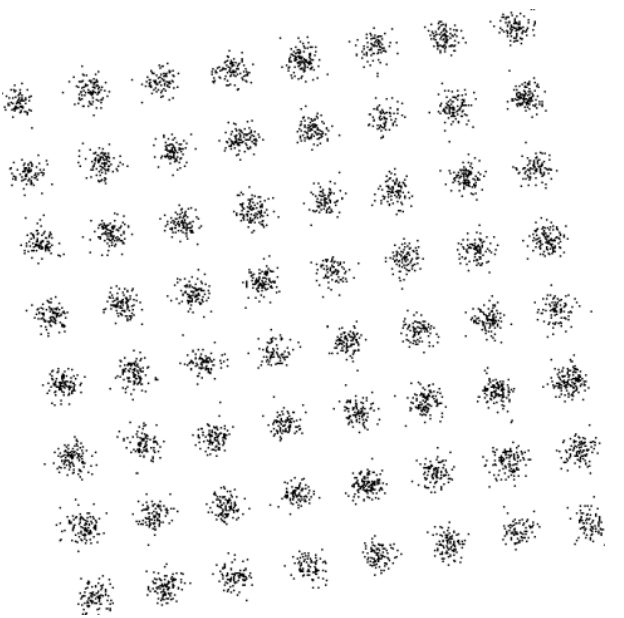

Figure 5. DVB-T2 standard signal at a level of 40,1 dBuV constellation diagram (modulation 64-QAM, 32k carrier, protection interval 1/32)

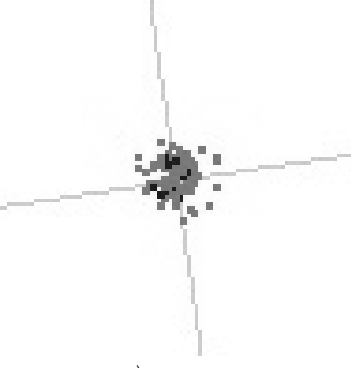

a)

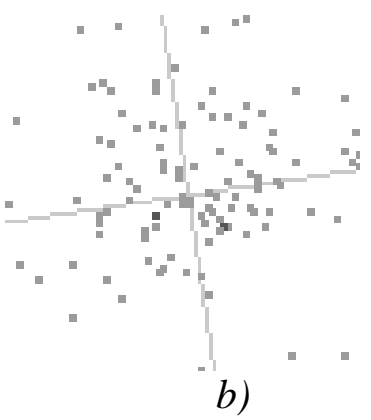

b)

Figure 6. Constellation diagram fragment a) signal level at the input is $60 \mathrm{dBuV}$;

b) signal level at the input is $40,1 \mathrm{dBuV}$

\section{Results}

The results of constellation diagrams' fragments image processing performed in ImageJ shows the ratio of direct and indirect measurements for on-air DTV systems with feedback (figure 7) [7].

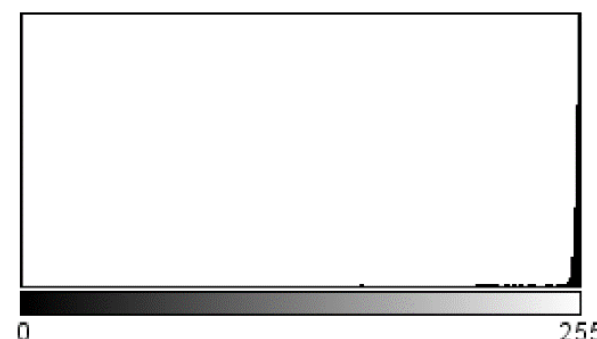

Count: 17940

Mean: 250.071

StdDev: 20.232

Min: 45

Max: 255

Mode: 255 (13876)

a)

Figure7. Histogram - a constellation diagramm fragment with the signal level

a) at the input of $60 \mathrm{dBuV}$; b) at the input of $40,1 \mathrm{dBuV}$

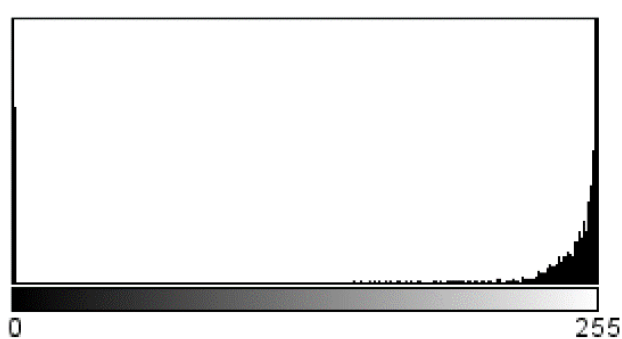

Count: 23560

Mean: 249.997

Min: 0

Max: 255

Mode: 255 (21200)

b) 


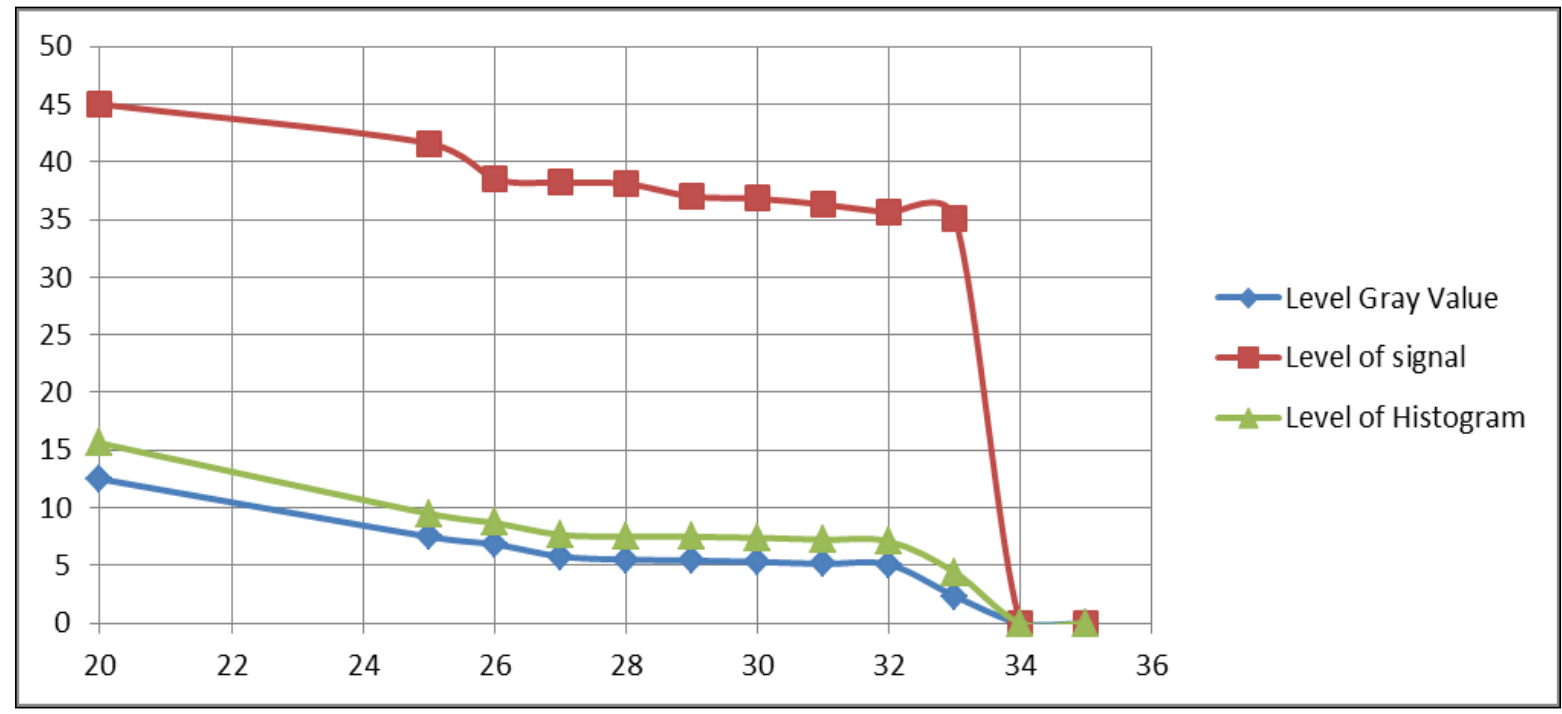

Figure 8. The ratio of direct and indirect measurements for on-air DTV systems

These results (figure 8) correlate with the results of MER measurement in the laboratory conditions. Precision of indirect measurements is not worse than the precision of the direct measurements. The given method may be used to estimate the quality of on-air DTV systems as well as to improve the possibilities of inspection devices that are used in television broadcasting.

The position of the I/Q modulator in the circuit can vary depending on how the DVB-T2 modulator is implemented in practice. The COFDM modulation is preceded by the channel coding, the error correction which is similar in DVB-T2 as in DVB-S satellite transmission.

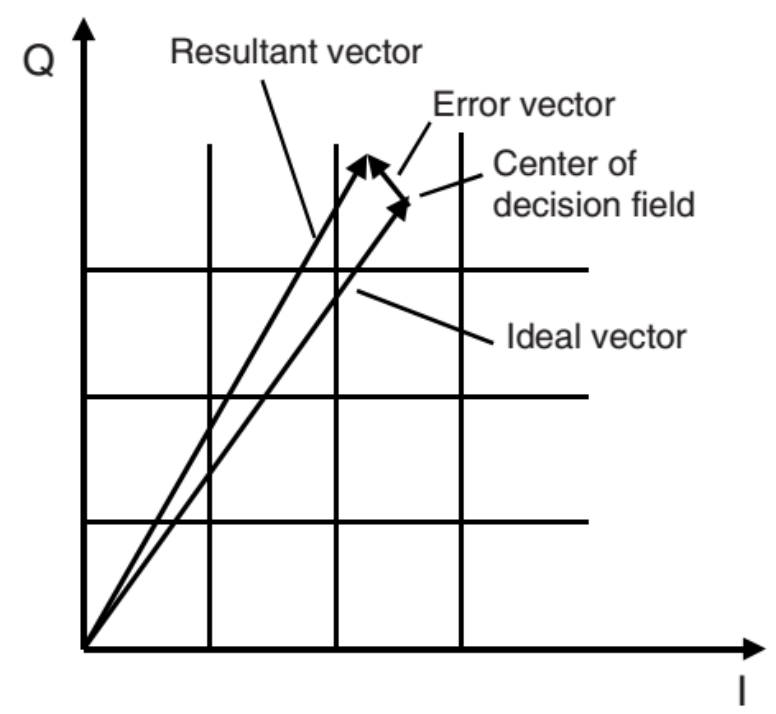

Figure 9. Error vector for determining the modulation error ratio

All the interference effects on a digital signal in broadcast TV previously explained cause the constellation points to exhibit deviations from their nominal position in the center of the decision fields.

If the deviations are too large, the decision thresholds will be exceeded, and bit errors are produced. However, the deviations from the decision field center can also be measurement parameters for the size of any interference quantity. 


\section{Conclusions}

What is the object of an artificial measurement parameter like the modulation error ratio? The MER measurement assumes that the actual hits in the constellation fields were pushed out of the center of the respective field by the interference quantities (figure 9).

The interference quantities were given error vectors and the error vector points from the center of the constellation field to the point of the actual hit in the constellation field. Then the lengths of all these error vectors were measured against time in each constellation field and the quadratic mean was formed or the maximum peak value was acquired in a time window [8]. This work has an applied character, its results are used in TV broadcasting.

The work was supported by the Russian Ministry of Science and Higher Education for Project No. 8.9562.2017 / 8.9 and the RFBR grant No. 16-47-700939.

\section{References}

1. Konroev A. Features of digitally modulated channel parameters measurement, 2010, Telesputnik №9, pp. 14-20.

2. ETSI EN 302755 V1.1.1 (2009-09) European Standard (Telecommunications series) Digital Video Broadcasting (DVB); Frame structure channel coding and modulation for a second generation digital terrestrial television broadcasting system (DVB-T2).

3. Kamenskiy A.V., Malanin M.U. Kuryachiy M.I. Measurement of television images resolution with using of software // Optoelectronic devices and devices in pattern recognition systems, image processing and character information. Recognition, 2015, Kursk, 12-16 may 2015, materials of XII International Scientific and Technical Conference. 2015: Southwestern State University (Kursk), pp. 235-237.

4. Imatest Documentation by Norman Koren. www.imatest.com/docs/ (date of the application: 07.04.2018).

5. Sidelnikov A., Stoukatch O., Hudeev R., Intelligent Noise Reduction Algorithm and Software Proceedings, The IEEE-Siberian Conference on Control and Communications (SIBCON2003), October 1-2 2003,Tomsk, 2003, pp. 87-88.

6. Digital Video and Audio Broadcasting Technology: A Practical Engineering Guide. Springer Science \& Business Media, 2010, 827 p.

7. Popov A., Kuryachiy M., Kapustin V. Improvement of noise immunity level for digital on-air video broadcasting systems Proceedings, IEEE 2015 International Siberian Conference on Control and Communications (SIBCON-2015), May 21-23, 2015.

8. Digital Video and Audio Broadcasting Technology. A Practical Engineering Guide. Fischer, 2010, XXVII, 800 p.

\section{UOT 004.04, 621.397.2}

Kuryaçiy Mixail İ. ${ }^{1}$, Kapustin Vyaçeslav V. ${ }^{2}$, Popov Aleksandr S. ${ }^{3}$

${ }^{1,2}$ Tomsk Dövlət İdarəetmə Sistemləri və Radioelektronika Universiteti, televiziya və idarəetmə kafedras1, Tomsk, Rusiya

${ }^{3}$ Rusiya televiziya və radio yayım şəbəkəsinin Kemerovo filialı, Kemerovo, Rusiya

${ }^{1}$ kur@tu.tusur.ru, ${ }^{2}$ peregnun@mail.ru, mailrus@bk.ru

OFDM siqnalının ulduz diaqramlarının təsvirləri əsasında rəqəmsal televiziya yayım sisteminin maneələrə davamlılıq səviyyəsinin qiymətləndirilməsi metodu

Rəqəmsal televiziyanın ötürücüləri üçün monitorinq sistemlərində rəqəmsal siqnalın keyfiyyətinə vaxtaşırı nəzarət edilməlidir. $\mathrm{Bu}$ sahədə aparılan tədqiqatlar aşağıdakı faktın olduğunu göstərmişdir. Ötürücünün normal fəaliyyəti zamanı onun MER-i $35 \mathrm{dBm} / \mathrm{mkV}$-dən az olmamalıdır. Lakin bəzi hallarda MER-in nominal səviyyəsində televiziya təsviri itir. Bu, ötürücünün dayaq siqnalının GPS desinxronizasiyası ilə əlaqədar baş verir və bilavasitə televiziya 
qəbuledicisindəki son təsvirə öz təsirini göstərir. Bu faktın müəyyən edilməsi məqsədilə OFDM siqnalının ulduz xəritəsinin təsviri təhlil edilməlidir. Təklif edilən metod COFDM bürclərinin təsvirlərinə əsaslanmaqla maneələrə davamlılıq səviyyəsini qiymətləndirməyə imkan verir.

Açar sözlər: DVB, DTV, manealara davamlılıq, MER, BER.

\section{УДК 004.04, 621.397.2}

Курячий Михаил И. ${ }^{1}$, Капустин Вячеслав В. ${ }^{2}$, Попов Александр S. ${ }^{3}$

${ }_{1,2}$ Кафедра телевидения и управления Томского государственного университета систем управления и радиоэлектроники, Томск, Россия

${ }^{3}$ Кемеровский филиал Российской телевизионной и радиовещательной сети, Кемерово, Российская Федерация

${ }^{1}$ kur@tu.tusur.ru, ${ }^{2}$ peregnun@mail.ru, ${ }^{3}$ mailrus@ @b.ru

Метод оценки уровня помехоустойчивости цифровой телевизионной системы телевещания на основе изображений звездных диаграмм OFDM сигнала

В системах мониторинга для передатчиков цифрового телевидения необходимо периодически контролировать качество цифрового сигнала. Исследования в этой области свидетельствуют о следующем факте. Во время нормальной работы передатчика его MER не должен опускаться ниже 35 дБм/мкВ. Но есть случаи, когда на номинальном уровне MER телевизионное изображение отсутствует. Это связано с GPS десинхронизации опорного сигнала передатчика и непосредственно влияет на конечное изображение на телевизионном приемнике. Чтобы установить этот факт, необходимо проанализировать изображение звездной карты сигнала OFDM. Предлагаемый метод позволяет оценить уровень помехоустойчивости, основываясь на изображениях созвездий COFDM.

Ключевые слова: $D V B, D T V$, помехоустойчивость, MER, BER. 